\title{
Clinical evidence of the nursing diagnosis Adult pressure injury*
}

\author{
Evidências clínicas do diagnóstico de enfermagem lesão por pressão em adulto \\ Evidencias clínicas del diagnóstico de enfermería lesión por presión en el adulto
}

How to cite this article:

Santos CT, Barbosa FM, Almeida T, Vidor ID, Almeida MA, Lucena AF. Clinical evidence of the nursing diagnosis Adult pressure injury. Rev Esc Enferm USP. 2021;55:e20210106. DOI: https://doi.org/10.1590/1980-220X-REEUSP-2021-0106

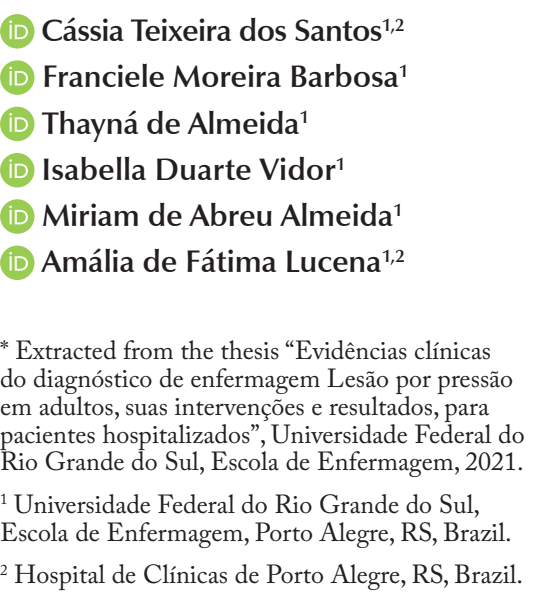

\begin{abstract}
Objective: To identify clinical evidence of the nursing diagnosis Adult pressure injury. Method: Cross-sectional study with 138 adult patients, with community-acquired or hospital-acquired pressure injuries, admitted to clinical, surgical, and intensive care units. Data collected from Electronic health records (EHR) and from the clinical assessment of patients at the bedside, analyzed through descriptive statistics. Results: The partial thickness loss of dermis presenting as a shallow open ulcer, intact or open/ ruptured blister, consistent with a stage II pressure injury, was the significant defining characteristic. Significant related factors were pressure on bony prominence, friction surface, shear forces, and incontinence. The population at significant risk was that at age extremes ( $\geq 60$ years). Significant associated conditions were pharmacological agent, physical immobilization, anemia, decreased tissue perfusion, and impaired circulation. Conclusion: The clinical indicators assessed in the patients showed evidence of the nursing diagnosis Adult pressure Injury, with significant lesions consistent with stage II, resulting from pressure, especially in elderly individuals, and in those on various medications.
\end{abstract}

\section{DESCRIPTORS}

Pressure Ulcer; Nursing Diagnosis; Nursing Process; Standardized Nursing Terminology; Evidence-Based Practice. 


\section{INTRODUCTION}

Pressure injury (PI) is an adverse event and a nursing indicator denoting low quality of care ${ }^{(1-3)}$. It shows high rates of prevalence in patients admitted to intensive care units (ICU), with a variability between 8 and $23 \%$ of cases, depending on patient severity and the risk factors presented ${ }^{(2-3)}$. In areas of admission of medical or surgical patients, PI prevalence can reach $10 \%$, generating a negative impact on their safety ${ }^{(4-7)}$.

Pressure injury represents the third most expensive health problem for health systems, third only to cancer and cardiovascular diseases ${ }^{(8-9)}$. Thus, both prevention and proper treatment of PI shall be prioritized by nurses, who are responsible for patient care 24 hours a day.

A key factor in the prevention of PI is the identification of its risk factors and the proper assessment of the lesion when it occurs. This recognition is performed by nurses in their daily clinical practice and requires scientific knowledge described in the literature and in guidelines on the subject $^{(3-4,8,10-12)}$. To qualify the predictive aspects for the development of PI and to guide preventive interventions, nurses can use the Nursing Diagnosis (ND) Risk for adult pressure injury NANDA International (NANDA-I)(13). However, when treating individuals who have already developed PI, the problem-focused ND, i.e. Pressure injury, also needed to be developed and was recently published in the 12th edition of NANDA-I 2021-2023, as a result of studies by the same group of researchers who developed the ND Risk for adult pressure injury ${ }^{(13)}$. However, it was noticed that the ND Adult pressure injury lacked clinical studies to determine the level of evidence LOE-3, determined by the NANDA-I taxonomy as an extremely important level to obtain testing and clinical proof of the ND falling in this classification ${ }^{(13)}$.

In the guideline Prevention and Treatment of Pressure Ulcers/Injuries: Clinical Practice Guideline used worldwide, $\mathrm{PI}$ is defined as "Localized damage to the skin and/or underlying tissue of an adult, as a result of pressure, or pressure in combination with shear; it usually occurs over a bony prominence but may also be related to a medical device or other object" ${ }^{\prime(2)}$. Based on this definition, it is understood that a study addressing the main clinical evidence of PI patients, taking the pathophysiology of this injury into account, would contribute to providing greater support for the identification of a more accurate ND and, consequently, to better decision-making by the nurse with interventions to solve or minimize this problem ${ }^{(10-11,14)}$.

Therefore, this study aims to search for clinical indicators associated with PI in hospitalized patients, besides contributing to the refinement of NANDA-I, supported by scientific evidence. Therefore, this research aims to identify clinical evidence of the ND Adult pressure injury.

\section{METHOD}

\section{Type of Study, Population and Local}

This is a cross-sectional, observational study conducted with PI patients in a large university hospital in southern Brazil.

\section{Selection Criteria}

Patients aged 18 years or over, admitted to clinical, surgical, and intensive care units, with community-acquired or hospital-acquired PI, with clinical evaluation by the researchers within 24 hours of notification of PI in the hospital's computerized system, the field of study, were included. Patients with cognitive impairment without the presence of a companion and patients without clinical conditions for PI evaluation were excluded.

\section{Sample Definition}

The sample calculation was based on the institution's incidence of PI, which represented a rate of $0.68 \%$ in 2017, and on the minimum positive sampling frequency of $50 \%$ (for the establishment of the diagnosis investigated), with a margin of error for the $95 \%$ confidence interval of 0.10 . Thus, the sample consisted of 138 adult patients hospitalized in medical, surgical, and intensive care units, with PI regardless of the stage of the lesion.

\section{Data Collection}

Data collection took place from January to September 2019 and was performed by the main researcher, two nurses, and four nursing students and undergraduate scientific research scholarship students, all with clinical and research knowledge on PI and on the use of NANDA-I ${ }^{(13)}$. It should be noted that there was a training for the collection, in which the main researcher provided in-person guidance, in two meetings of approximately two hours each, in which he used power point and photos on the assessment, classification, prevention, and treatment of PI, and performed, at the bedside, clinical evaluations of patients with PI to demonstrate the use of the collection instrument and, thus, avoid bias and differences in the identification of variables among the collectors. The data collection instrument was designed and refined by the researchers, and supervised by the study supervisor, a senior researcher. The instrument includes all the variables described in the study.

It consisted of sociodemographic and clinical variables, which were collected from the patient's Electronic health records (EHR). The sociodemographic variables were age, sex, color, profession, religion, and level of education. The continuous variables selected were weight, height, Body Mass Index (BMI), length of stay, and Braden Scale score. The categorical variables selected were comorbidities, reason for admission, time of development of the PI (community or in hospital) and PI site.

The variables described as clinical indicators of the ND were collected through the patient's clinical assessment at the bedside. For this, the following defining characteristics were listed: intact skin with non-blanchable redness of a localized area, usually over a bony prominence; partial thickness loss of dermis presenting as a shallow open ulcer, intact or open/ruptured blister; full thickness tissue loss, subcutaneous fat may be visible, but bone, tendon or muscle are not exposed; full-thickness tissue loss with exposed bone, tendon or muscle, slough, or eschar may be present on some 
parts of the wound bed, often including undermining and tunneling; full thickness tissue loss in which the base of the ulcer is covered by slough (yellow, tan, gray, green or brown) and/or eschar (tan, brown or black) in the wound bed; purple or brown localized area of discolored intact skin or bloodfilled blister, due to damage of underlying soft tissue from pressure and/or shear.

The related factors were pressure over bony proeminence, surface friction, shearing forces, incontinence, insufficient caregiver knowledge of pressure injury prevention, dehydration and extremes of weight. The Populations at risk were: extreme of age ( $\geq 60$ years) and history of pressure injury. The associated conditions were pharmaceutical agent (corticosteroids, non-steroidal anti-inflammatory drug, chemotherapy and radiotherapy, immunosuppressants, painkillers and anxiolytics); physical immobilization; anemia; decreased in tissue perfusion; decreased in tissue oxygenation; decrease in serum albumin level; impaired circulation; sensory perception limitations; edema; peripheral neuropathy; hyperthermia, and smoking ${ }^{(2-4,9-13)}$.

It should be noted that in the assessment regarding the defining characteristics, related factors, populations at risk, and associated conditions, conceptual and operational definitions were developed, based on previous studies ${ }^{(12-13)}$, as well as literature search in the SciELO, CINAHL, and PubMed databases using the descriptors: Pressure injury; Nursing diagnosis; Nursing process; Standardized Terminology in Nursing; Evidence-Based Clinical Practice. The literature review was carried out in July 2018 and full articles published in the period from 2013 to 2018 in Portuguese, Spanish and English were considered. Based on this review, a synthesis was carried out, linked to previous studies, which supported the construction and revision of definitions to maintain the reliability of the data evaluated in the data collection instrument.

Patients were enrolled for the study through the PI notification performed by the nurse in the facility's computerized system and by the daily active search performed by the researchers in the units described above. Initially, the sociodemographic, continuous, and categorical variables were collected in electronic health records and, subsequently, the variables related to the clinical indicators of the ND Adult pressure injury were collected at the patient's bedside. Data collection was performed by two collectors in the first 30 patients; after that, the kappa test was performed, which showed high agreement $(\mathrm{k}>0.85)$ between the collectors, which allowed the collection to be continued individually. Each patient's assessment lasted about 20 minutes.

\section{Data Analysis and Treatment}

Data were organized in a database in the software Windows Excel with double typing and exported to the software SPSS, version 21.0, analyzed using descriptive statistics, with a significance level of $5 \%$ being adopted. Continuous variables were described as mean and standard deviation or median and interquartile range, according to data distribution. Categorical variables were expressed as absolute and relative frequencies.

\section{Ethical Aspects}

This research was carried out with human beings in accordance with Resolution 466/12. The research project was approved by the Ethics and Research Committee of the institution under protocol 2018-0390, opinion number 2.796.427 and approval in 2018. All participants signed the Free Informed Consent Form.

Table 1 - Sociodemographic and clinical characterization of patients with Pressure Injury ( $\mathrm{n}=138)$ - Porto Alegre, RS, Brazil 2019.

\begin{tabular}{|c|c|}
\hline Variables & $N(\%)$ \\
\hline \multicolumn{2}{|l|}{ Sociodemographic characteristics } \\
\hline Age* & 64.8 years $(+/-17.3)$ \\
\hline Male $^{+}$ & $76(55)$ \\
\hline Caucasians $^{+}$ & $116(84)$ \\
\hline Black $^{+}$ & $14(10)$ \\
\hline Married $^{+}$ & $64(46)$ \\
\hline Widower $^{+}$ & $33(24)$ \\
\hline Some elementary schoolt & $60(46.5)$ \\
\hline Retired $^{+}$ & $54(39)$ \\
\hline Catholic religion $^{+}$ & $88(64)$ \\
\hline \multicolumn{2}{|l|}{ Reasons for admission } \\
\hline Sepsis $^{+}$ & $15(11)$ \\
\hline Cancer $^{+}$ & $13(9.4)$ \\
\hline Pain $^{+}$ & $12(9.0)$ \\
\hline Hip and/or knee prosthesis ${ }^{+}$ & $11(8.0)$ \\
\hline Dyspnea $^{+}$ & $8(6.0)$ \\
\hline Lowered level of consciousness $^{+}$ & $7(5.1)$ \\
\hline Urinary infection $^{+}$ & $6(4.6)$ \\
\hline \multicolumn{2}{|l|}{ Comorbidities } \\
\hline Systemic Arterial Hypertension $(\mathrm{SAH})^{+}$ & $82(59.4)$ \\
\hline Cardiovascular disease $^{\dagger}$ & $65(47)$ \\
\hline Diabetes Mellitus (DM) ${ }^{+}$ & $52(38)$ \\
\hline Neurological disorders ${ }^{\dagger}$ & $51(37)$ \\
\hline Abstinent smokers $^{+}$ & $41(30)$ \\
\hline Neoplasm $^{+}$ & $34(27)$ \\
\hline Active smoker ${ }^{\dagger}$ & $26(19)$ \\
\hline Kidney disease $^{+}$ & $24(17.4)$ \\
\hline Respiratory diseases $^{\dagger}$ & $23(17)$ \\
\hline
\end{tabular}

\section{Other clinical features}

Body mass index*

$23.9 \mathrm{~kg} / \mathrm{m}^{2}(+/-5.8)$

Low weight $\left(\mathrm{BMI}<18.5 \mathrm{~kg} / \mathrm{m}^{2}\right)^{+}$

21 (15.2)

Obesity $\left(\mathrm{BMI}>30 \mathrm{~kg} / \mathrm{m}^{2}\right)^{+}$

$21(15.2)$

Length of hospital stay ${ }^{\ddagger}$

19 days (10-35.5)

PI developed during hospitalization ${ }^{\dagger}$

88 (64)

PI developed in the community ${ }^{\dagger}$

50 (36)

$\mathrm{PI}$ in the sacral region ${ }^{+}$

$109(79)$

$\mathrm{Pl}$ in the heel region ${ }^{\dagger}$

15 (10)

Note: *Mean \pm standard deviation; ${ }^{\dagger} \mathrm{n}(\%) ;{ }^{\ddagger}$ Median $(25-75$ percentile) Source: research data. 


\section{RESULTS}

The mean age of patients was $64.8(+/-17.3)$ years, with sepsis (11\%), neoplastic disease (9.4\%), and pain (9\%) as the main reasons for admission; most of them were hypertensive (59.4\%) and diabetic (38\%). PI developed during hospitalization in $64 \%$ of cases, most frequently (79\%) in the sacral region (Table 1).

The Braden Scale assessment showed that 83 (60\%) patients were bedfast, 85 (62\%) occasionally moist, $50(36.2 \%)$ sensory perception very limited, 83 (60\%) with very limited mobility, 51 (40\%) with probably inadequate nutrition, and 68 (49\%) with friction and shear problem. Braden Scale mean total score was $14( \pm 3)$ points, that is, a moderate risk for PI.
Among the defining characteristics of PI, the most frequently evidenced were partial thickness loss of dermis presenting as a shallow open ulcer, intact or open/ruptured blister in 75 (54.4\%) patients, followed by full thickness tissue loss, subcutaneous fat may be visible, but bone, tendon or muscle are not exposed in $21(15.3 \%)$ patients (Table 2).

\section{DISCUSSION}

The study results allowed highlighting the indicators of the ND Adult pressure injury in clinical practice, which can guide nurses in the precise judgment regarding this injury. According to the literature consulted ${ }^{(2-3,8,10-13)}$, what differentiates PI from other types of tissue damage is its pathophysiology. Its classification is based on the inspection

Table 2 - Frequency of defining characteristics, related factors, populations at risk and associated conditions of the ND Adult pressure injury $(n=138)$. Porto Alegre, RS, Brazil 2019.

\begin{tabular}{|c|c|c|}
\hline & $\mathbf{n}$ & $\%$ \\
\hline \multicolumn{3}{|l|}{ Defining characteristics } \\
\hline Partial thickness loss of dermis presenting as a shallow open ulcer, intact or open/ruptured blister (consistent with a stage II PI) & 75 & 54.4 \\
\hline Full thickness tissue loss, subcutaneous fat may be visible, but bone, tendon or muscle are not exposed (consistent with Stage III PI) & 21 & 15.3 \\
\hline Intact skin with non-blanchable redness of a localized area, usually over a bony prominence (consistent with Stage I PI) & 18 & 13 \\
\hline $\begin{array}{l}\text { Purple or brown localized area of discolored intact skin or blood-filled blister due to damage to underlying soft tissue from } \\
\text { pressure and/or shear (consistent with Suspected PI of deep tissue injury) }\end{array}$ & 13 & 9.4 \\
\hline $\begin{array}{l}\text { Full thickness tissue loss in which the base of the ulcer is covered by slough (yellow, tan, gray, green or brown) and/or eschar } \\
\text { (tan, brown or black) in the wound bed (consistent with Unstageable PI) }\end{array}$ & 6 & 4.3 \\
\hline $\begin{array}{l}\text { Full-thickness tissue loss with exposed bone, tendon or muscle, slough or eschar may be present on some parts of the wound } \\
\text { bed, often including undermining and tunneling (consistent with Stage IV PI) }\end{array}$ & 5 & 3.6 \\
\hline \multicolumn{3}{|l|}{ Related factors } \\
\hline Pressure over bony prominence & 133 & 96.4 \\
\hline Surface friction & 130 & 94.2 \\
\hline Shearing forces & 129 & 93.5 \\
\hline Insufficient caregiver knowledge of pressure injury prevention & 102 & 74 \\
\hline Incontinence & 93 & 67.4 \\
\hline Dehydration & 67 & 49 \\
\hline Extremes of weight & 42 & 30.4 \\
\hline \multicolumn{3}{|l|}{ Populations at risk } \\
\hline Extreme of age ( $\geq 60$ years) & 93 & 67.4 \\
\hline History of pressure injury & 51 & 37 \\
\hline \multicolumn{3}{|l|}{ Associated conditions } \\
\hline $\begin{array}{l}\text { Pharmaceutical agent (corticosteroids, non-steroidal anti-inflammatory drug, chemotherapy and radiotherapy, } \\
\text { immunosuppressants, painkillers and anxiolytics) }\end{array}$ & 136 & 98 \\
\hline Anemia & 100 & 72.5 \\
\hline Physical immobilization & 122 & 88 \\
\hline Decrease in tissue perfusion & 92 & 68 \\
\hline Impaired circulation & 83 & 60 \\
\hline Sensory perception limitations & 64 & 46.7 \\
\hline Edema & 56 & 41 \\
\hline Peripheral neuropathy & 55 & 40 \\
\hline Decrease in serum albumin level & 49 & 35.5 \\
\hline Decrease in tissue oxygenation & 34 & 24.6 \\
\hline Smoking & 26 & 19 \\
\hline Hyperthermia & 12 & 8.7 \\
\hline
\end{tabular}

Source: research data. 
of the types of tissue injured, taking the injury thickness, the appearance of the bed and its edges into account, which also allows the assessment of the different defining characteristics (DC) of the ND Adult pressure Injury.

Thus, the most frequent DC (54.4\%) observed was "Partial thickness loss of dermis presenting as a shallow open ulcer, intact or open/ruptured blister", consistent with Category/Stage II $\mathrm{PI}^{(12)}$. This stage of the injury is highly frequent in clinical practice ${ }^{(5,15)}$ and highlights the need for nurses to make an early diagnosis of the injury, or even at an earlier stage $e^{(5)}$, to prevent its worsening.

The second most frequent DC, identified in 21 (15.3\%) patients, was "Full thickness tissue loss, subcutaneous fat may be visible, but bone, tendon or muscle are not exposed", consistent with Category/Stage III PI. In this type of lesion, skin fat can be observed and there may be granulation tissue and epibole, with variable tissue damage depth ${ }^{(12)}$.

The DC "Intact skin with non-blanchable redness of a localized area, usually over a bony prominence", consistent with Stage/Category I PI ${ }^{(12)}$ was present in 18 (13\%) patients. Research shows a high prevalence of stage I and II PI in hospitalized patients ${ }^{(6,16)}$. The worldwide use of PI guidelines $^{(12)}$ by health professionals seems to be having an effect on clinical practice, since these more severe injuries have been less frequent. In this regard, it is understood that the use of nursing classification systems, such as NANDA-I, incorporated into clinical practice, can also contribute to better patient care outcomes, both in the prevention and treatment of PI, since they subsidize the nurse in the diagnostic evaluation and, consequently, in the establishment of a more accurate care plan.

Thirteen (9.4\%) patients showed the DC "Purple or brown localized area of discolored intact skin or blood-filled blister due to damage to underlying soft tissue from pressure and/or shear", consistent with suspected PI of deep tissue injury. This characteristic results from an intense and/or prolonged pressure and shear at the bone-muscle interface; it can progress quickly and reveal the current extension of the lesion or resolve without tissue loss ${ }^{(12)}$. To be better evaluated in individuals with pigmented or dark skin, the nurse has to observe for subepidermal moisture, changes in the consistency and temperature of the skin, and the presence of pain in the region ${ }^{(17)}$.

The DC "Full thickness tissue loss in which the base of the ulcer is covered by slough (yellow, tan, gray, green or brown) and / or eschar (tan, brown or black) in the wound bed" was found in $6(4.3 \%)$ patients, being consistent with Unstageable $\mathrm{PI}^{(12)}$. The DC "Full-thickness tissue loss with exposed bone, tendon or muscle, slough or eschar may be present on some parts of the wound bed, often including undermining and tunneling" consistent with Category/ Stage IV PI ${ }^{(12)}$ was identified in 5 (3.6\%) patients, all of which being community-acquired injuries. These PI stages are considered the most severe, as injury infection is usually associated with chronicity of the underlying disease, and with factors related to PI. In addition, the study patients presented sepsis (11\%) as the main reason for hospitalization and a median length of stay of 19 days, which indicates the severity of their clinical condition ${ }^{(15)}$.

Thus, all the defining characteristics evaluated denoted clinical evidence of PI, according to its stage. Three related factors were more frequent, "Pressure over bony prominence", "Surface friction" and "Shear forces", considered basic etiologies for the rapid development of $\mathrm{PI}^{(5,16,18)}$. Moreover, almost half of the patients had problems related to friction and shear, according to the Braden Scale scores, with PI mainly in the sacral region, an area of bony prominence undergoing high pressure. These findings are in line with the literature ${ }^{(5,12,16)}$ and show the relevance of these factors to the ND Adult pressure injury, being important diagnostic indicators ${ }^{(13)}$.

Besides the previously mentioned related factors, "Insufficient caregiver knowledge of pressure injury prevention" was also found in 100 (74\%) patients, denoting strong evidence as a component of the ND Adult pressure injury. It should be noted that PI prevention is also related to the knowledge of the patients and their caregivers, and that the nursing team needs to instruct them on prevention and treatment actions ${ }^{(16,18)}$.

The related factors "Incontinence", present in 93 (68\%) patients, and "Dehydration", in 67 (49\%) patients, refer to the condition of skin hydration. These factors make up the skin's microclimate, that is, with the increase in temperature and humidity (perspiration, exudate, and body fluids) the skin becomes more vulnerable and less rigid. In contrast, dehydrated or dry skin is more susceptible to cracking, demonstrating that the microclimate affects the skin structure and function, accelerating the development of $\mathrm{PI}^{(12,19)}$.

Patients had a mean BMI of $23.9 \mathrm{~kg} / \mathrm{m}^{2}$, considered normal weight for the adult population; however, 42 (30.4\%) patients had extremes of weight, data that is consistent with probably inadequate nutrition, which is important evidence to the ND Adult pressure injury. Both obesity and malnutrition, besides increasing the incidence of clinical complications, also cause delay in PI healing ${ }^{(20)}$. Excess weight triggers hypoperfusion and ischemia in the adipose tissue, and worsens the individual's chronic disease conditions and hinders their repositioning and locomotion ${ }^{(9,20-21)}$.

The population at risk "Extremes of age ( $\geq 60$ years)" characteristic was present in 93 (67\%) patients, who were considered elderly in Brazil $^{(22)}$; patients' mean age was 64.8 (+/-17.3) years, corroborating the fact that the elderly are a population at risk for the ND Adult pressure injury. Skin collagen and elastic fibers reduction, the change in its thickness and texture impair tissue perfusion and are a result of $\operatorname{aging}^{(9,20)}$.

Moreover, regarding the population at risk, it should be noted that $36 \%$ of patients have already been admitted to the hospital with PI, which makes us think that this worsening may also have occurred, in part, due to the deficient knowledge of family members or caregivers, who shall be instructed by the nurse during hospitalization, as recommended in the literature and main guidelines ${ }^{(12-13,23)}$. Thus, it should be noted that the patient who is hospitalized with PI is part of the population at risk "History of pressure injury" of the ND Adult pressure injury. 
The associated condition "Pharmaceutical agent (corticosteroids, non-steroidal anti-inflammatory drug, chemotherapy and radiotherapy, immunosuppressants, painkillers and anxiolytics)" was more frequent in the study (99\%). This condition is intrinsically related to the reason for hospitalization, besides comorbidities and chronic diseases, which require the continuous use of these medications that interfere with healing, decrease tissue resistance and immunity, favoring an increase in infections, and reduce the patient's mobility, enhancing pressure and shear and increasing the permanence of $\mathrm{PI}^{(7,24)}$.

The associated condition "Anemia", found in 122 (88\%) patients, and the "Decreased in serum albumin level", in 49 (35.5\%) patients, corroborate literature data ${ }^{(25)}$ that indicate a significant association between the low serum levels of hemoglobin and albumin with the development of PI. It is known that the decrease in the amount of hemoglobin in the bloodstream causes a decrease in oxygen to the fibroblasts, responsible for tissue healing ${ }^{(9)}$; in its turn, the decrease in serum albumin causes changes in oncotic pressure and interstitial edema, reducing perfusion to tissues, leading to PI development and worsening ${ }^{(25,26)}$.

"Physical immobilization" was found in 100 (72.5\%) patients, and, according to Braden Scale scores, $60 \%$ of them were bedfast and with very limited mobilization. This condition is considered a clinical indicator for high risk of PI, being relevant to both the ND Adult pressure injury and the ND Risk for adult pressure injury. Studies show ${ }^{(16,19)}$ that staying immobile on a support surface for a long time will cause irreversible damage to the skin, as is the case of patients exposed to prolonged surgeries or patients with neurological diseases ${ }^{(19,27)}$.

"Decreased in tissue perfusion" was present in 92 (67\%) patients. This situation occurs when blood vessels fail to dilate in response to the need for blood flow, reducing the supply of oxygen and nutrition to tissues and favoring PI development ${ }^{(9,16,28)}$. The "Decreased in tissue oxygenation", present in $34(25 \%)$ patients, is a factor observed mainly in individuals with cardiovascular and respiratory diseases. Associated with this, it was found that $59.4 \%$ of patients had SAH, $47 \%$ cardiovascular diseases, $38 \% \mathrm{DM}$, and $17 \%$ respiratory diseases, which clinically evidences the conditions that are associated with the ND Adult pressure injury.

Subsequently, the associated conditions "Impaired circulation", "Sensory perception limitations" and "Peripheral neuropathy" proved to be important factors for PI development. This is explained by its frequency identified in this research and in other studies ${ }^{(9,25,28)}$, which showed a significant association between these conditions and PI.

The associated condition "Edema", present in 56 (41\%) patients, is considered an indirect factor for PI, that is, it requires other factors such as immobility and pressure and shear forces to lead to damage ${ }^{(12,16)}$. The associated condition "Smoking" was identified in 19\% of the patients, many of them being abstinent smokers. Smoking causes a decrease in the amount of functional hemoglobin in the blood and tissue oxygenation, and wound healing delays ${ }^{(11)}$; therefore, it also favors PI development or delays in its treatment success.

"Hyperthermia" was the least frequent associated condition (9\%). However, studies show that body temperature can affect the susceptibility and tolerance of the skin, affecting the transport of oxygen to the tissue. A Japanese study pointed out that at the end of a six-hour surgery, the patient's core temperature of $38.1^{\circ} \mathrm{C}$ had a higher odds ratio than those with a lower core temperature to develop $\mathrm{PI}^{(19)}$.

A limitation of the study is the small sample size, considering the different stages of PI, which prevented associations between its related factors, populations at risk, associated conditions and defining characteristics from being made.

The clinical evidence presented by the study corroborates the incorporation of the ND Adult pressure injury to the LOE 3 evidence level of the NANDA-I diagnostic terminology, so that it gives support to the work of nurses who daily assess, diagnose, and treat PI. The results presented also contribute to the development of knowledge, teaching, and research in the nursing area related to wound care.

\section{CONCLUSION}

The study allowed the identification of a set of clinical evidences of the ND Adult pressure injury, which includes six defining characteristics, consistent with the stages of PI: intact skin with non-blanchable redness of a localized area, usually over a bony prominence; partial thickness loss of dermis presenting as a shallow open ulcer, intact or open/ ruptured blister; full thickness tissue loss, subcutaneous fat may be visible, but bone, tendon or muscle are not exposed; full-thickness tissue loss with exposed bone, tendon or muscle, slough, or eschar may be present on some parts of the wound bed, often including undermining and tunneling; full thickness tissue loss in which the base of the ulcer is covered by slough (yellow, tan, gray, green or brown) and/ or eschar (tan, brown or black) in the wound bed; purple or brown localized area of discolored intact skin or bloodfilled blister, due to damage to the underlying soft tissue from pressure and/or shear. Six related factors: surface friction, shearing forces, pressure over bony proeminence, incontinence, insufficient caregiver knowledge of pressure injury prevention, dehydration and extremes of weight. Two populations at risk: extremes of age ( $\geq 60$ years) and history of pressure injury. Twelve associated conditions: pharmaceutical agent - corticosteroids, non-steroidal antiinflammatory drug, chemotherapy and radiotherapy, immunosuppressants, painkillers and anxiolytics -, anemia, physical immobilization, impaired circulation, decrease in tissue perfusion, decrease in serum albumin level, edema, alteration in sensation, decrease in tissue oxygenation, hyperthermia, peripheral neuropathy and smoking.

These diagnostic identifiers found at the patients' bedside proved to be important evidence for what we call ND Adult pressure injury. 


\section{RESUMO}

Objetivo: Identificar evidências clínicas do diagnóstico de enfermagem Lesão por pressão em adulto. Método: Estudo transversal com 138 pacientes adultos, com lesão por pressão de origem comunitária ou desenvolvida na internação, hospitalizados em unidades clínicas, cirúrgicas e de terapia intensiva. Dados coletados em prontuário de saúde eletrônico e na avaliação clínica dos pacientes à beira do leito, analisados pela estatística descritiva. Resultados: A perda parcial da derme, apresentando-se como úlcera aberta ou bolha intacta ou rompida, compatível com lesão por pressão estágio II, foi a característica definidora significativa. Os fatores relacionados significativos foram: pressão sobre proeminência óssea, superfície de atrito/fricção, forças de cisalhamento e incontinência. A população em risco significativa foi extremo de idade ( $\geq 60$ anos). As condições associadas significativas foram: agente farmacológico, imobilização física, anemia, diminuição da perfusão tecidual e circulação prejudicada. Conclusão: Os indicadores clínicos avaliados nos pacientes demonstraram evidências do diagnóstico de enfermagem Lesão por pressão em adulto, sendo significativas as lesões compatíveis com o estágio II, decorrentes da pressão, principalmente em indivíduos idosos, e em uso de diversos medicamentos.

\section{DESCRITORES}

Lesão por pressão; Diagnóstico de Enfermagem; Processo de Enfermagem; Terminologia Padronizada em Enfermagem; Prática Clínica Baseada em Evidências.

\section{RESUMEN}

Objetivo: Identificar evidencias clínicas del diagnóstico de enfermería Lesión por presión en el adulto. Método: Estudio transversal con 138 pacientes adultos, con lesión por presión de origen comunitario o desarrollado durante hospitalización en unidades clínicas, quirúrgicas y terapia intensiva. Datos recolectados en histórico electrónico de salud y durante evaluación clínica de los pacientes ingresados, analizados a través de la estadística descriptiva. Resultados: La pérdida parcial de la epidermis con aspectos de úlcera abierta o ampollada intacta o desgarrada, compatible con lesión por presión etapa II, fue la característica definidora significativa. Los factores relacionados significativos fueron: presión sobre prominencia ósea, superficie de fricción, fuerzas de cizallamiento e incontinencia. La población en riesgo significativo fue extremo de edad ( $\geq 60$ años). Las condiciones asociadas significativas fueron: agente farmacológico, inmovilización física, anemia, disminución de la perfusión tisular y circulación sanguínea perjudicada. Conclusión: Los indicadores clínicos evaluados en los pacientes demostraron evidencias del diagnóstico de enfermería Lesión por presión en el adulto, siendo que fueron significativas las lesiones compatibles con la etapa II, resultantes de la presión, principalmente en individuos mayores, y que utilizan diversos fármacos.

\section{DESCRIPTORES}

Úlcera por Presión; Diagnóstico de Enfermería; Proceso de Enfermería; Terminología Normalizada de Enfermería; Práctica Clínica Basada en la Evidencia.

\section{REFERENCES}

1. Squitieri L, Waxman DA, Mangione CM, Saliba D, Ko CY, Needleman J, Ganz DA. Evaluation of the Present on Admission Indicator among Hospitalized Fee for Service Medicare Patients with a Pressure Ulcer Diagnosis: Coding Patterns and Impact on Hospital Acquired Pressure Ulcer Rates. Health Serv Res. 2018;53:2970-87. DOI: http://dx.doi.org/10.1111/1475-6773.12822

2. Coyer F, Miles S, Gosley S, Fulbrook P, Sketcher-Baker K, Cook JL, et al. Pressure injury prevalence in intensive care versus non-intensive care patients: a state-wide comparison. Australian Crit Care. 2017;30(5):244-250. DOI: http://dx.doi.org/10.1016/j.aucc.2016.12.003

3. Chaboyer WP, Thalib L, Harbeck EL, Coyer FM, Blot S, Bull CF, et al. Incidence and prevalence of pressure injuries in adult intensive care patients: A systematic review and meta-analysis. Crit Care Med. 2018;46(11):e1074-e1081. DOI: http://dx.doi.org/10.1097/ CCM.0000000000003366

4. Biçer EK, Güçlüel Y, Türker M, Kepiçoglu NA, Sekerci YG, Say A. Pressure Ulcer Prevalence, Incidence, Risk, Clinical Features, and Outcomes Among Patients in a Turkish Hospital: A Cross-sectional, Retrospective Study. Wound Manag Prev [Internet]. 2019 [cited 2020 Dec 15];65(2):20-28. Available from: https://www.o-wm.com/article/pressure-ulcer-prevalence-incidence-risk-clinical-featuresand-outcomes-among-patients

5. Constantin AG, Moreira APP, Oliveira JLC, Hofstätter LM, Fernandes LM. Incidence of pressure injury in an adult intensive care unit. Estima. 2018;16:e1118. DOI: http://dx.doi.org/10.1030886/estima.v16.454_PT

6. Borghardt AT, Prado TN, Bicudo SDS, Castro DS, Bringuente MEO. Pressure ulcers in critically ill patients: incidence and associated factors. Rev Bras Enferm. 2016;69(3):460-67. DOI: http://dx.doi.org/10.1590/0034-7167.2016690307i

7. Jomar RT, Jesus RP, Jesus MP, Gouveia BR, Pinto EN, Pires AS. Incidence of pressure injury in an oncological intensive care unit. Rev Bras Enferm. 2019;72(6):1566-71. DOI: https://dx.doi.org/10.1590/0034-7167-2018-0356

8. Torra-Bou JE, Verdú-Soriano J, Sarabia-Lavin R, Paras-Bravo P, Soldevilla-Ágreda JJ, García-Fernández FP. Las úlceras por presión como problema de seguridad del paciente. Gerokomos [Internet]. 2016 [cited 2020 Out 5];27(4):161-167. Available from: http://scielo.isciii. es/pdf/geroko/v27n4/07_helcos6.pdf

9. Jaul E, Barron J, Rosenzweig JP, Menczel J. An overview of co-morbidities and the development of pressure ulcers among older adults. BMC Geriatr. 2018;18(1):1-11. DOI: https://dx.doi.org/10.1186/s12877-018-0997-7

10. Santos CTD, Almeida MDA, Oliveira MC, Victor MADG, Lucena ADF. Development of the nursing diagnosis risk for pressure ulcer. Rev Gaucha Enferm. 2015;36(2):113-121. DOI: https://dx.doi.org/10.1590/1983-1447.2015.02.49102

11. Santos CTD, Almeida MDA, Lucena ADF. The Nursing Diagnosis of risk for pressure ulcer: content validation. Rev Lat Am Enfermagem. 2016;24(2):e2693. DOI: https://dx.doi.org/10.1590/1518-8345.0782.2693

12. European Pressure Ulcer Advisory Panel, National Pressure Injury Advisory Panel and Pan Pacific Pressure Injury Alliance. Prevention and Treatment of Pressure Ulcers/Injuries: Clinical Practice Guideline. The International Guideline; 2019.

13. Herdman HT, Kamitsuru S, Lopes CT. NANDA International Nursing Diagnoses: definitions \& classification 2021-2023. Twelfth edition. Thieme: Thieme Medical Publishers; 2021. 
14. Ferreira RC, Duran ECM. Clinical validation of nursing diagnosis "00085 Impaired Physical Mobility" in multiple traumas victims. Rev Lat Am Enfermagem. 2019;27:e3190. DOI: http://dx.doi.org/10.1590/1518-8345.2859.3190

15. Pachá HHP, Faria JIL, Oliveira KAD, Beccaria LM. Pressure Ulcer in Intensive Care Units: a case-control study. Rev Bras Enferm. 2018;71(6):3027-3034. DOI: http://dx.doi.org/10.1590/0034-7167-2017-0950

16. Celik B, Karayurt Ö, Ogce, F. The Effect of Selected Risk Factors on Perioperative Pressure Injury Development. AORN J. 2019;110(1): 29-38. DOI: https://doi.org/10.1002/aorn.12725

17. Gunowa NO, Hutchinson M, Brooke J, Jackson D. Lesões por pressão em pessoas com tons de pele mais escuros: uma revisão da literatura. J Clin Nurs. 2018;27(17-18):3266-3275. DOI: https://doi.org/10.1111/jocn.14062

18. Balzer K, Kremer L, Junghans A, Halfens RJG, Dassen T, Kottner J. What patient characteristics guide nurses' clinical judgement on pressure ulcer risk? A mixed methods study. International Int J Nurs Stud. 2014;51(5):703-716. DOI: http://dx.doi.org/10.1016/j. ijnurstu.2013.09.005

19. Yoshimura M, lizaka S, Kohno M, Nagata O, Yamasaki T, Mae T, et al. Risk factors associated with intraoperatively acquired pressure ulcers in the park bench position: a retrospective study. Int Wound J. 2016;13(6):1206-1213. DOI: https://doi.org/10.1111/iwj.12445

20. Kayser SA, VanGilder CA, Lachenbruch C. Predictors of superficial and severe hospital-acquired pressure injuries: A cross-sectional study using the International Pressure Ulcer Prevalence ${ }^{\mathrm{TM}}$ survey. Int J Nurs Stud. 2019;89:46-52. DOI: https://doi.org/10.1016/j. ijnurstu.2018.09.003

21. Souza SA, Silva AB, Cavalcante UMB, Lima CMBL, Souza TC. Adult obesity in different countries: an analysis via beta regression models. Cad. Saúde Publica. 2018;34(8):e00161417. DOI: http://dx.doi.org/10.1590/0102-311X00161417

22. World Health Organization. Active ageing: A policy framework [Internet]. Geneva: World Health Organization; 2002 [cited 2020 Dec 15]. Available from: https://www.who.int/ageing/publications/active_ageing/en/

23. Ferreira JDL, de Aguiar ESS, de Lima CLJ, de Brito KKG, Costa MML, Soares MJGO. Preventive Actions against Pressure Ulcers in Elderly with Functional Decline of Physical Mobility at Home Environment. Estima. 2016;14(1):36-42. DOI: https://doi.org/10.5327/Z18063144201600010006

24. Coleman S, Nelson EA, Vowden P, Vowden K, Adderley U, Sunderland L, et al. Development of a generic wound care assessment minimum data set. J Tissue Viability. 2017;26(4):226-40. DOI: https://doi.org/10.1016/j.jtv.2017.09.007

25. Sprigle S, McNair D, Sonenblum S. Pressure Ulcer Risk Factors in Persons with Mobility-Related Disabilities. Adv Skin Wound Care. 2020;33:146-154. DOI: https://doi.org/10.1097/01.ASW.0000653152.36482.7d

26. Karg P, Ranganathan VK, Churilla M, Brienza D. Sacral skin blood flow response to alternating pressure operating room overlay. J Tissue Viability. 2019;28:75-80. DOI: https://doi.org/10.1016/j.jtv.2019.03.001

27. Lima LB, Staub MM, Cardozo MCE, Bernardes DS, Silva ERR. Clinical indicators of nursing outcomes classification for patient with risk for perioperative positioning injury: A cohort study. J Clin Nurs. 2019;28:4367-4378. DOI: https://doi.org/10.1111/jocn.15019

28. Cox J, Roche S. Vasopressors and development of pressure ulcers in adult critical care patients. Am J Respir Crit Care Med. 2015;24(6): 501-510. DOI: https://doi.org/10.4037/ajcc2015123 